\title{
STUDIA NAD STRATYGRAFIĄ I POZIOMAMI ARCHITEKTONICZNO-UŻYTKOWYMI ZAMKU KRUSZWICKIEGO ${ }^{1}$
}

\author{
STUDIES OF STRATIGRAPHY; THE ARCHITECTURAL \\ AND USABLE LAYERS OF THE CASTLE IN KRUSZWICA
}

\begin{abstract}
The castle in Kruszwica was built after 1343, at the request of Casimir III the Great. The oldest written sources, Kronika by Jan of Czarnków, dates the construction of the castle back to 1350-1355. The castle hosted the seat of the starost, judiciary authorities and a prison. In 1973-1982, the excavations were located in the central and south-western parts of the Castle Hill. In 2007-2008, the archaeological excavations were moved to the crests of the Hill; in 2010-2011 they were located chiefly near the structures of the castle building, still uncovered in 1973-1982. As a result, relics of the castle house were excavated together with several cellar rooms and fragments of the peripheral wall with remains of a gate. Following the results of stratigraphic and architectural analyses, the results of the research into the movable historic material, coupled with the results of ${ }^{14} \mathrm{C}$ radiocarbon dating, four chronological periods have been identified in the history of the castle in Kruszwica: period I - since the mid-14 $4^{\text {th }}$ c. to 1519 ; period II after 1519 to 1591 ; period III - after 1591 to 1657; period IV - after 1657.
\end{abstract}

Keywords: Kruszwica, castle, Middle Ages, modern age, stratigraphy, chronology.

* ORCID 0000-0001-5095-8100, Muzeum Archeologiczne w Poznaniu, ul. Wodna 27, 61-781 Poznań, e-mail: piotr.pawlak@muzarp.poznan.pl.

${ }^{1}$ Niniejszy tekst jest częścią artykułu napisanego w ramach projektu NPRH Mit, tradycje i rzeczywistość materialna. Kruszwica. Od wczesnopiastowskiego grodu do zamku kruszwickiego, którego prowadzącym, z ramienia IAiE PAN Oddział w Poznaniu, był dr hab. Wojciech Dzieduszycki. Temat stratygrafii Wzgórza Zamkowego (stan. 2) został wcześniej poruszony w artykule P. Pawlaka (1993, s. 215-232), ale dotyczył tylko odkrytej w latach 1973-1982 „kamienicy” zamkowej. Do tej pory żadne opracowania dotyczące Zamku w Kruszwicy nie poruszały kwestii układów stratyfikacyjnych i ich chronologii. W niniejszym artykule zatem po raz pierwszy próbuje się kwestie stratygrafii Zamku w Kruszwicy potraktować całościowo, obejmując swym zasięgiem wszystkie dotychczasowe wykopy badawcze zlokalizowane na Wzgórzu Zamkowym. 
Zamek w Kruszwicy zbudowany został na polecenie Kazimierza Wielkiego, prawdopodobnie po 1343 roku. Najstarsze źródło pisane, Kronika Jana z Czarnkowa, podaje czas wzniesienia zamku na lata 1350-1355. Sam Kazimierz Wielki przebywał w Kruszwicy w latach 1358, 1359, 1365 i 1368. W Zamku znajdowała się siedziba starosty, władz sądowniczych oraz więzienie. W 1655 roku Zamek zajęli Szwedzi i zniszczyli go całkowicie w 1657 roku. Do naszych czasów ocalała jedynie ośmioboczna wieża z przylegającymi do niej resztkami murów obwodowych (Dzieduszycki 2014, s. 15-27; Maciejewski 2014, s. 53-87).

W zachowanych lustracjach, spisanych w latach 1616-1620, wymienia się „kamienicę”, „budowanie stare”, „budowanie nowe” i wieżę. Główny budynek znajdował się w południowej części zamku. Posiadał obszerną piwnicę, a w niej „komór siedem”. Na parterze usytuowane były pomieszczenia reprezentacyjno -mieszkalne. Wspomina się także, iż „budowanie nowe” miało trzy kondygnacje. Znajdowała się tutaj kuchnia, izba sądowa i komory służebnych. „Budowanie stare" było już w czasie lustracji podniszczone i „na wierzchu obleciało". Nad budynkiem bramnym znajdowała się izba. Ponadto wymieniana jest łaźnia i browar. Wyposażenie zamku w tym okresie było skromne i zużyte. Lustrator zauważył, że „piec, tylko rozwalony”, „stolik bez nóg” (Dzieduszycki 2014, s. 28-31; Małachowicz 2014, s. 94-97).

Najstarszy zachowany widok Zamku w Kruszwicy pochodzi z czasów zajęcia zamku przez Szwedów (ryc. 1). Rysowany był przez naczelnego inżyniera obozów szwedzkich Erika Jönsona Dahlbergha, a rytowany przez Willema Swiddego w 1694 roku. Rycina opublikowana została w 1696 roku w dziele S. de Pufendorfa, pod tytułem De rebus a Carolo Gustavo Sveciae Rege gestis commentatorum libri septem elegantissimus tabulis aeneis exornati cum triplici indice. To najbardziej znany obecnie widok zamku kruszwickiego, pomimo zwierciadlanego odwrócenia wykonanej odbitki. Pozostałe widoki zamku w Kruszwicy pochodzą z wieku XIX oraz lat 20.-30. XX wieku (Dzieduszycki 2014, s. 32-33; Maciejewski 2014, s. 53-76).

\section{ANALIZA}

Po drugiej wojnie światowej, w ramach Kierownictwa Badań nad Początkami Państwa Polskiego, podjęto systematyczne prace wykopaliskowe na terenie dawnego grodu piastowskiego w Kruszwicy. Kierował nimi R. Jakimowicz. Po 1951 roku prace kontynuowane były przez Katedrę Archeologii Polski Uniwersytetu im. A. Mickiewicza w Poznaniu, a następnie przez Kruszwicką Stację Archeologiczną Instytutu Historii Kultury Materialnej PAN, pod kierownictwem W. Hensla, przy współudziale A. Cofty-Broniewskiej, E. Springer i W. Dzieduszyckiego. Badania 


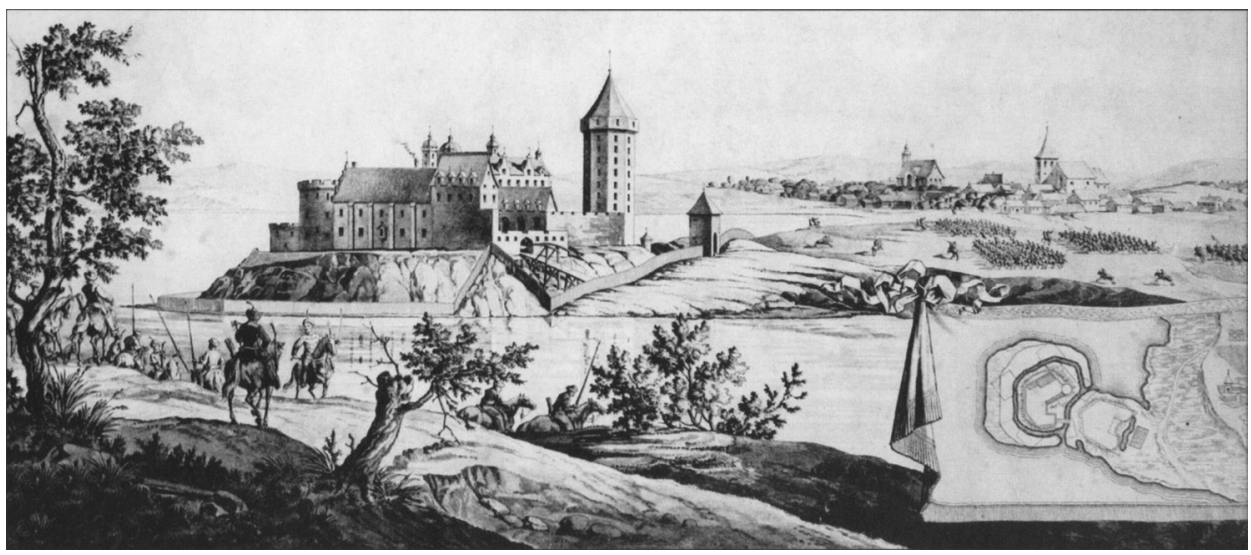

Ryc. 1. Widok zamku w Kruszwicy rysowany przez E.J. Dahlbergha, rytowany przez W. Swiddego w 1694 roku, opublikowany w dziele S. de Pufendorfa De rebus a Carolo Gustavo Sveciae Rege gestis commentatorum libri septem elegantissimus tabulis aeneis exornati cum triplici indice w 1696/1697 roku (wersja odwrócona)

te objęły pierwotnie przestrzeń na tzw. Przygródku (stan. 4, 4a, 5), a następnie, w latach 1973-1982 na Wzgórzu Zamkowym (stan. 2). Skoncentrowano się tutaj głównie na rozpoznaniu reliktów architektury zamkowej, z której najbardziej widoczną pozostałością była tylko ośmioboczna tzw. Mysia Wieża, z przylegającymi do niej fragmentami zachodniego i północnego muru obwodowego. Kolejne badania, pod kierunkiem W. Dzieduszyckiego, przeprowadzono w latach 2007-2008 i 2010-20112. Prace te miały na celu weryfikację dotychczasowej wiedzy o zamku. Skoncentrowały się zarówno na rozpoznaniu założeń architektonicznych, lokalizacji budowli, murów obronnych, baszt, umiejscowienia bramy i prowadzącego do niej mostu, jak i pozyskania elementów wyposażenia oraz źródeł materialnych dokumentujących życie codzienne mieszkańców warowni.

Pierwotnie zamek kruszwicki obejmował swym zasięgiem całe Wzgórze Zamkowe. W latach 1973-1982 wykopy badawcze zlokalizowano w części centralnej i południowej Wzgórza w celu rozpoznania sytuacji stratygraficznej w rejonie dziedzińca oraz ewentualnego odsłonięcia budynków zamkowych. W latach 2007-2008 wykopy usytuowane były na krawędziach Wzgórza w celu weryfikacji istnienia murów obwodowych oraz bramy. W latach 2010-2011 natomiast wykopy badawcze

2 W latach 2007-2008 badania prowadził Instytut Archeologii i Etnologii PAN Oddział w Poznaniu, w latach 2010-2011 firma ARCHKO Pracownia Archeologiczno-Konserwatorska z Poznania w ramach projektu „Goplańskie dziedzictwo kulturowe i przyrodnicze Kruszwicy bazą dla turystyki, rekreacji, edukacji i sportu". Dokonano wtedy konserwacji i nadbudowy obwodu murów Zamku wraz $\mathrm{z}$ adaptacją odsłoniętych ponownie piwnic oraz wybudowano punkt widokowy przy ekspozycji bramy zamkowej. 


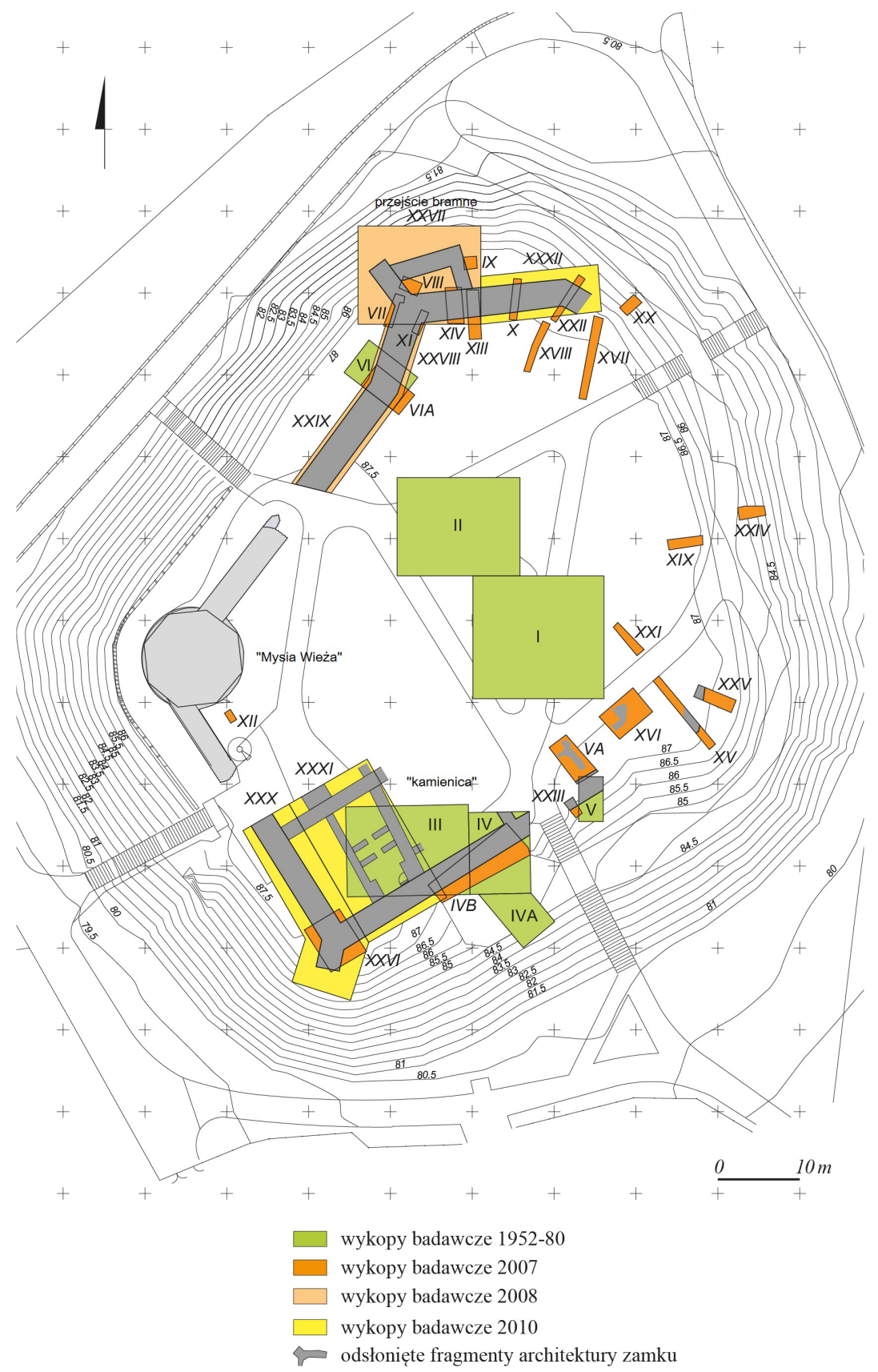

Ryc. 2. Kruszwica, stan. 2. Lokalizacja wykopów badawczych i odkrytych elementów architektury zamku. Opr. P. Pawlak, J. Kurkowicz 
umiejscowione zostały głównie w rejonie odsłoniętej już w latach 1973-1982 konstrukcji „kamienicy” zamkowej w celu jej odbudowy i rekonstrukcji (ryc. 2).

W wykopach badawczych zlokalizowanych w centralnej części Wzgórza Zamkowego udało się zaobserwować i zadokumentować cały układ stratygraficzny, od najstarszych obiektów kultury łużyckiej, poprzez warstwy i obiekty kulturowe związane z najstarszym osadnictwem grodowym, przechodząc z kolei przez obiekty i warstwy związane z powstaniem i funkcjonowaniem zamku, aż po nawarstwienia współczesne (ryc. 3). Spągi wykopów zarejestrowano na głębokości około 6,50 m poniżej poziomu terenu, którego rzędna wynosiła około 87,30 m n.p.m. Powyżej, do około 3,60 m p.p.t. odnotowano nawarstwienia wczesnośredniowieczne, datowane do początku XII wieku. Jeszcze wyżej znajdowały się już warstwy kulturowe związane $\mathrm{z}$ powstaniem, funkcjonowaniem i zniszczeniem zamku oraz nowożytne warstwy niwelacyjne, a także współczesny humus. W trakcie prowadzonych studiów okazało się, że brakuje nawarstwień z końca XII i warstw XIII-wiecznych. Być może uległy one zniszczeniu podczas prac niwelacyjnych pod budowę zamku, chociaż w wykopie II natrafiono na warstewkę brunatnej próchnicy z fragmentami węgli drzewnych, o miąższości do około $8 \mathrm{~cm}$, która mogłaby być śladem spalenia grodu w XIII wieku (1271) (ryc. 3:8). Znajdujące się nad nią warstwy drobnego gruzu ceglanego z zaprawą wapienną oraz warstwa brunatnej próchnicy to z pewnością już pozostałości po budowie zamku w połowie XIV wieku i związane z jego funkcjonowaniem przynajmniej do pierwszego pożaru w 1519 roku (ryc. 3:7, 7a). Z kolei ciemnobrunatne warstwy próchnicy $\mathrm{z}$ fragmentami węgli drzewnych i spalenizną to prawdopodobnie ślady tegoż pożaru, a warstwy drobnego gruzu ceglanego i gruzu przemieszane miejscami z zaprawą wapienną to niewątpliwie pozostałości remontu zamku po tymże pożarze (ryc. 3:5, 5a, 6). Znajdujące się nad nimi warstwy drobnego gruzu ceglanego z drobnymi fragmentami węgli drzewnych oraz jasnobrunatna próchnica z fragmentami węgli drzewnych to najprawdopodobniej warstwy kulturowe związane $\mathrm{z}$ funkcjonowaniem zamku w wieku XVI, do pożaru w 1591 roku, lub też krótko po nim (ryc. 3:4, 4a). Wyżej zarejestrowano warstewkę zbitej gliny oraz pozostałości bruku kamiennego, świadczące o użytkowaniu zamku po pożarze w 1591 roku, a także warstwy brunatnej próchnicy z fragmentami węgli drzewnych oraz gruzem ceglanym (ryc. 3:3). Powyżej znajdowały się już warstwy szarej próchnicy z gruzem ceglanym i zaprawą wapienną związane z destrukcją zamku przez Szwedów w 1657 roku (ryc. 3:2) oraz nawarstwienia nowożytne w postaci szarej i ciemnoszarej próchnicy (ryc. 3:1). We wschodniej części wykopu I, na głębokości około 2,25-3,35 m p.p.t. natrafiono na pozostałości konstrukcji ceglanej, być może pieca, związanego z funkcjonowaniem w zamku ogrzewania typu hypocaustum, powstałego prawdopodobnie po pożarze w 1519 roku. Wymiary konstrukcji wynosiły około 3,60 × $2 \times 0,90 \mathrm{~m}$. W tym samym wykopie, w części północno-wschodniej, na głębokości około 0,50-1,05 m p.p.t., odsłonięto pozostałości nawierzchni dziedzińca zamku w postaci fragmentu bruku kamiennego oraz poziomo ułożonych cegieł, pochodzących 


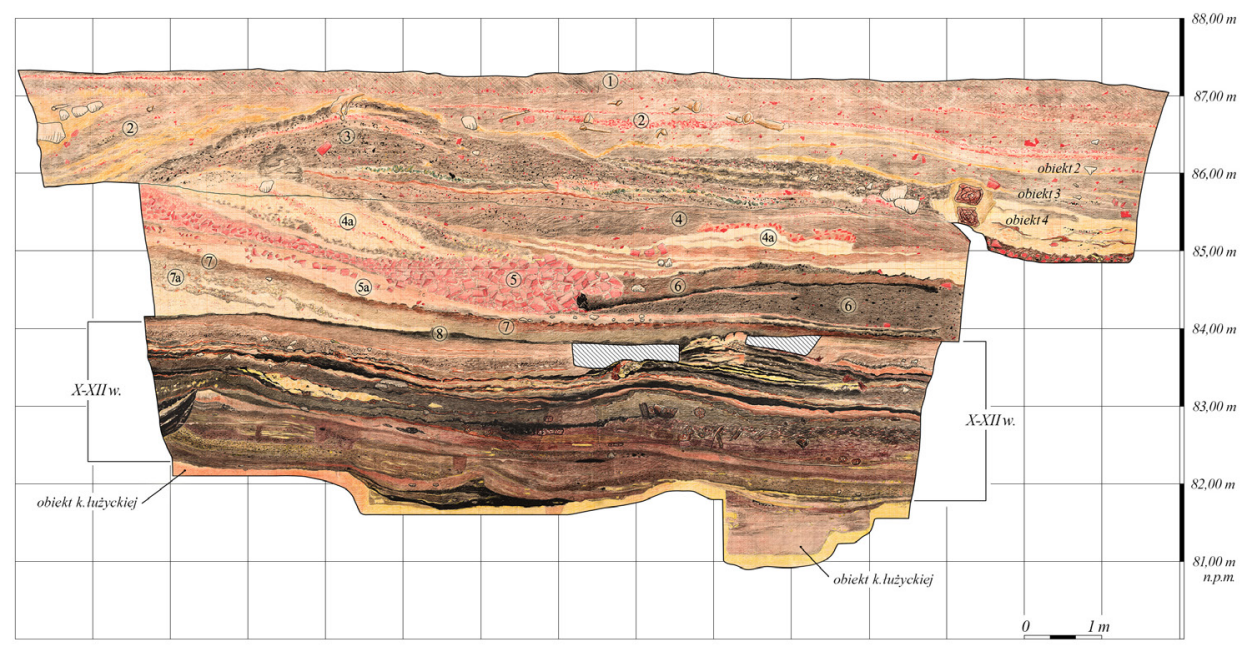

Ryc. 3. Kruszwica, stan. 2. Wykop II, profil N:

1 - szara i ciemnoszara próchnica; 2 - szara próchnica z gruzem ceglanym i zaprawą wapienną; 3 - brunatna próchnica z fragmentami węgli drzewnych i gruzem ceglanym; 4 - jasnobrunatna próchnica $\mathrm{z}$ fragmentami węgli drzewnych; $4 \mathrm{a}$ - drobny gruz ceglany z drobnymi fragmentami węgli drzewnych; 5 - gruz ceglany z zaprawą wapienną; 5a - drobny gruz ceglany; 6 - ciemnobrunatna próchnica z fragmentami węgli drzewnych i spalenizną; 7 - brunatna próchnica; $7 \mathrm{a}$ - drobny gruz ceglany z zaprawą wapienną; 8 - brunatna próchnica z fragmentami węgli drzewnych. Rys. K. Poprawski. Opr. J. Kurkowicz

prawdopodobnie z okresu funkcjonowania zamku w latach 1591-1657. Wyraźnie widoczna jest też kulminacja warstw kulturowych w części środkowej omawianych wykopów.

W wykopach badawczych zlokalizowanych w południowo-zachodniej części Wzgórza Zamkowego, kilkanaście centymetrów pod powierzchnią ówczesnego poziomu terenu, odkryto pozostałości „kamienicy” zamkowej, która zajmowała niemal całą powierzchnię wykopów (ryc. 4, 5) (Pawlak 1993, s. 215-232; Małachowicz 2014, s. 89-113). Zorientowana była na osi N-S i przylegała do odsłoniętego kamiennego fundamentu muru obwodowego, w południowo-zachodnim narożniku zamku. Wymiary odsłoniętej konstrukcji „kamienicy” wynosiły 13,90 x 13,30 m. $\mathrm{Z}$ budynku zachowała się tylko część piwniczna, w postaci czterech pomieszczeń i łączącego je korytarza. Poziomy odsłoniętych ceglanych progów, fragment zachowanej ceglanej posadzki oraz spagi warstw z gruzem ceglanym wyznaczyły orientacyjne poziomy użytkowe odkrytych pomieszczeń piwnicznych $(83,55-83,76 \mathrm{~m}$ n.p.m.). Wypełniska tych pomieszczeń to warstwy destrukcyjno-zasypiskowe związane bezpośrednio z konstrukcją budynku zamkowego i jego zniszczeniem w 1657 roku. W warstwach tych znaleziono liczne przedmioty zabytkowe będące 


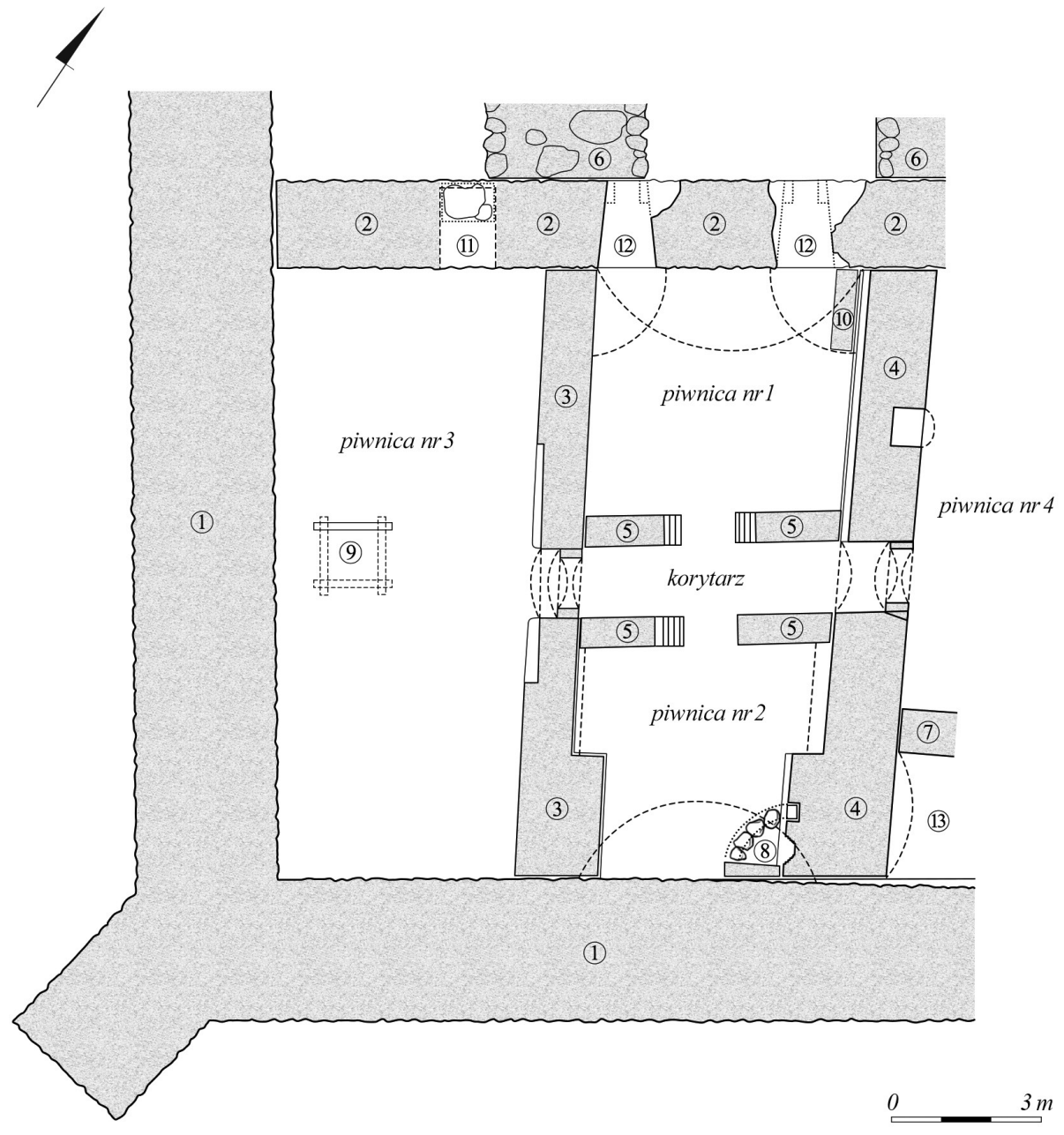

Ryc. 4. Kruszwica, stan. 2. Odkryte elementy architektury „kamienicy” zamkowej: 1 - mur obwodowy; 2 - ściana północna; 3-7 - ściany tworzące wewnętrzny podział piwnic; 8 - „kominek”; 9 - „piwniczka” zasobowa; 10 - zachowany fragment sklepienia; 11 - zejście do piwnicy;

12 - otwory okienne; 13 - „komora”. Opr. J. Kurkowicz, P. Pawlak (wg Małachowicz 2014, s. 99)

elementami wyposażenia poszczególnych pomieszczeń odkrytego budynku, pochodzące $\mathrm{z}$ ostatniej fazy funkcjonowania zamku. $\mathrm{Z}$ kolei warstwy kulturowe i materiał zabytkowy w nich zawarty, zalegające poniżej poziomów użytkowych odkrytych piwnic to prawdopodobnie nawarstwienia bezpośrednio związane $\mathrm{z}$ budową zamku w połowie XIV wieku i starsze.

Korytarz. Łączył ze sobą cztery pomieszczenia piwniczne. Jego długość wynosiła około $5,30 \mathrm{~m}$, szerokość około $1,5 \mathrm{~m}$, a zachowana wysokość ścian, zbudowanych $\mathrm{z}$ cegieł $\mathrm{w}$ wątku gotyckim, miejscami w wątku wendyjskim, sięgała do 


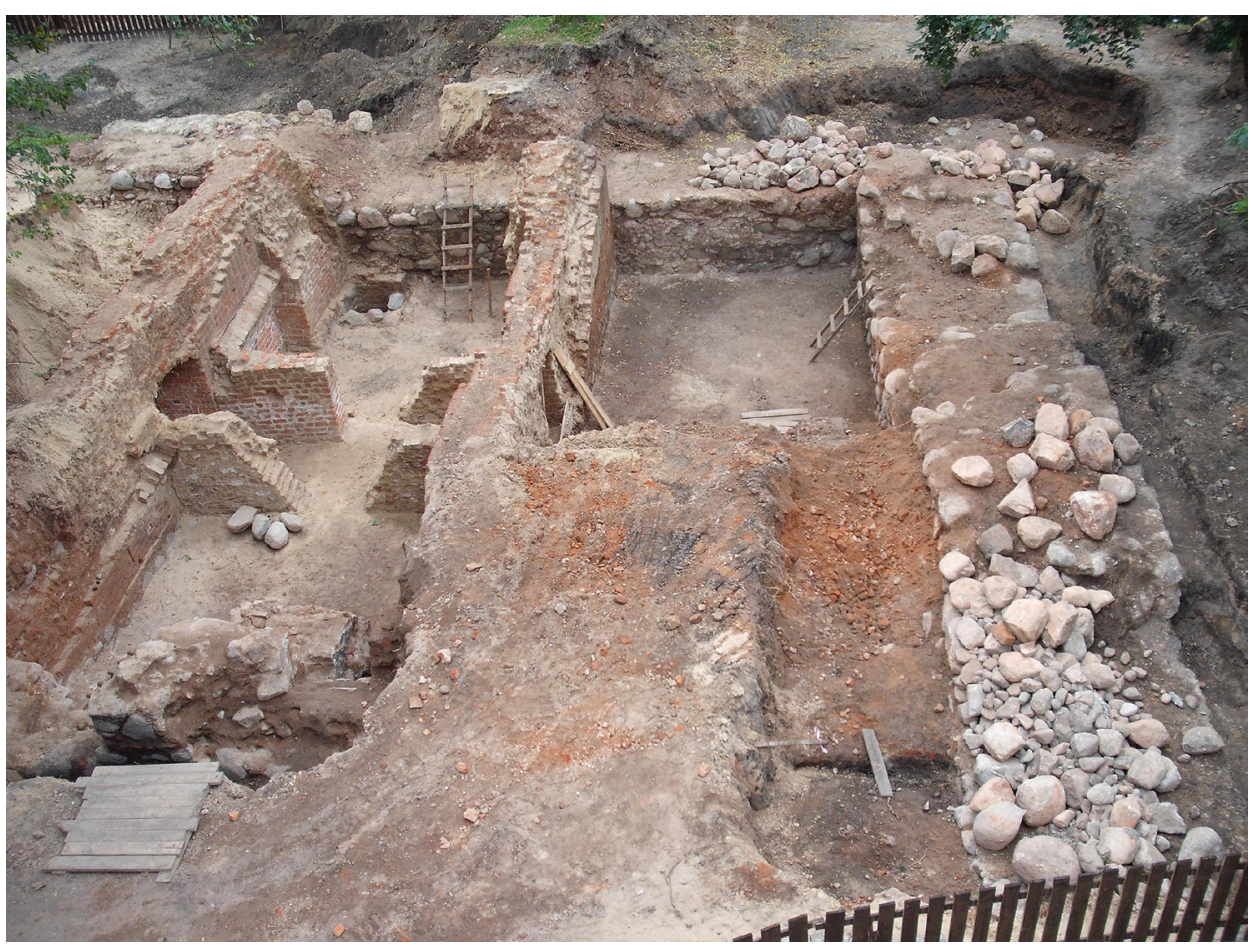

Ryc. 5. Kruszwica, stan. 2. Odkryte w latach 1973-1982 i 2010-2011 elementy architektury zamkowej „kamienicy”. Fot. P. Pawlak

około 1,90 m. Ich grubość z kolei wynosiła około 0,60 m. Korytarz przykrywało prawdopodobnie niezachowane ceglane sklepienie kolebkowe. Mniej więcej w połowie długości korytarza znajdowały się zachowane wejścia do dwóch piwnic. Podobne wejścia, ale z nietkniętymi łukowatymi sklepieniami z cegieł, utrzymały się na obu końcach korytarza. W wejściu do piwnicy po stronie południowej korytarza odsłonięto fragment ceglanej posadzki (83,70 m n.p.m.) o długości około $1 \mathrm{~m}$, a na koronie ściany nad tym wejściem odnotowano ślady wydeptania świadczące prawdopodobnie o istnieniu w tym miejscu niezachowanego przejścia pierwszej kondygnacji budynku. Z kolei na południowej ścianie wejścia do korytarza od strony wschodniej znajdowały się wyryte ostrym narzędziem napisy, z których czytelna była data A.D. 1591 (ryc. 6). Jest to data drugiego pożaru zamku i najprawdopodobniej data jego odbudowy. Wypełnisko korytarza (ryc. 7), na poziomie użytkowym, stanowiła warstwa jasnobrunatnej próchnicy $\mathrm{z}$ drobnym gruzem ceglanym, spalenizną i soczewkami żółtej gliny (ryc. 7:5). Nad nią znajdowały się warstwy zaprawy wapiennej z gruzem ceglanym i popiołem oraz ciemnobrunatnej próchnicy z gruzem ceglanym i spalenizną (ryc. 7:3,4). Powyżej zalegała warstwa jasnobrunatnej próchnicy z gruzem ceglanym i spalenizną, będąca zapewne stropem 


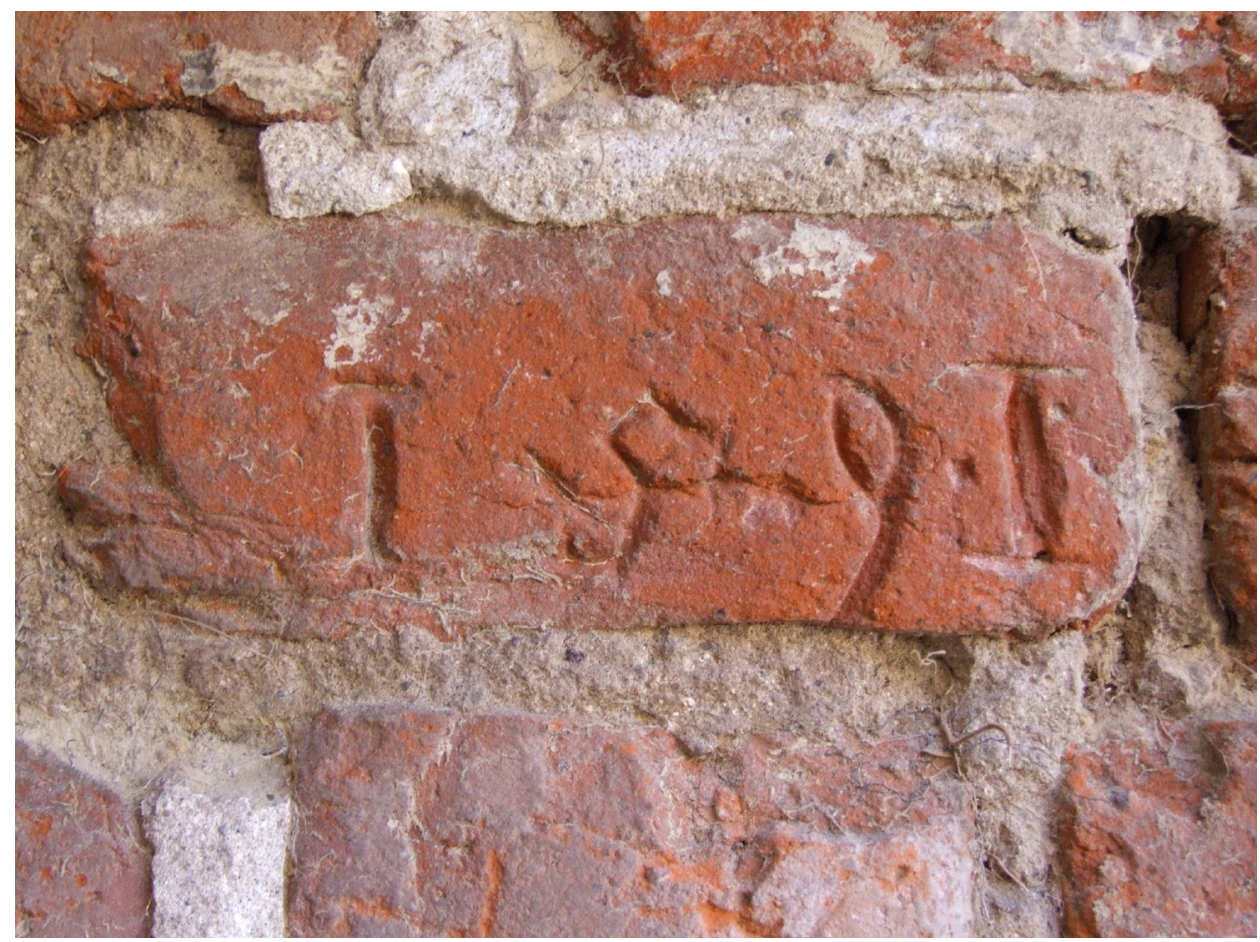

Ryc. 6. Kruszwica, stan. 2. Data 1591 wyryta na jednej ze ścian korytarza w pomieszczeniach piwnicznych „kamienicy” zamkowej. Fot. P. Pawlak

pomieszczeń piwnicznych oraz ciemnobrunatna próchnica z gruzem ceglanym, zaprawą wapienną i spalenizną (ryc. 7:1, 2). Obie te warstwy przedzielone były soczewkami ciemnożółtego piasku z węgielkami drzewnymi. Węgielki drzewne były prawdopodobnie pozostałością drewnianej podłogi pierwszej kondygnacji. Opisane warstwy to przypuszczalnie destrukt będący wynikiem zniszczenia zamku przez Szwedów w 1657 roku. Całość tych nawarstwień przykryta była warstwą gruzu ceglanego, zaprawy wapiennej ze spalenizną i szarobrunatną próchnicą, powstałą po roku 1657. Poniżej poziomu użytkowego korytarza odnotowano warstwę brunatnej spiaszczonej próchnicy przemieszanej $\mathrm{z}$ piaskiem, gliną oraz drobnym gruzem ceglanym związaną prawdopodobnie $\mathrm{z}$ budową zamku w połowie XIV wieku, a pod nią z kolei jeszcze starszą warstwę brunatno-czarnej próchnicy. Poziomu gruntu pierwotnego (calca) nie osiągnięto.

Piwnica 1. Znajdowała się po północnej stronie korytarza. Jej kształt był zbliżony do kwadratu o wymiarach około $5,10 \times 5,30 \mathrm{~m}$. Zachowane do wysokości około 3,60 m dwie ściany, zachodnią i wschodnią, o grubości około 1,0-1,30 m, zbudowano $\mathrm{z}$ cegieł $\mathrm{w}$ wątku gotyckim na fundamencie $\mathrm{z}$ kamieni. Miejscowo odnotowano wpleciony wątek wendyjski. Podobnie zbudowana była ściana 


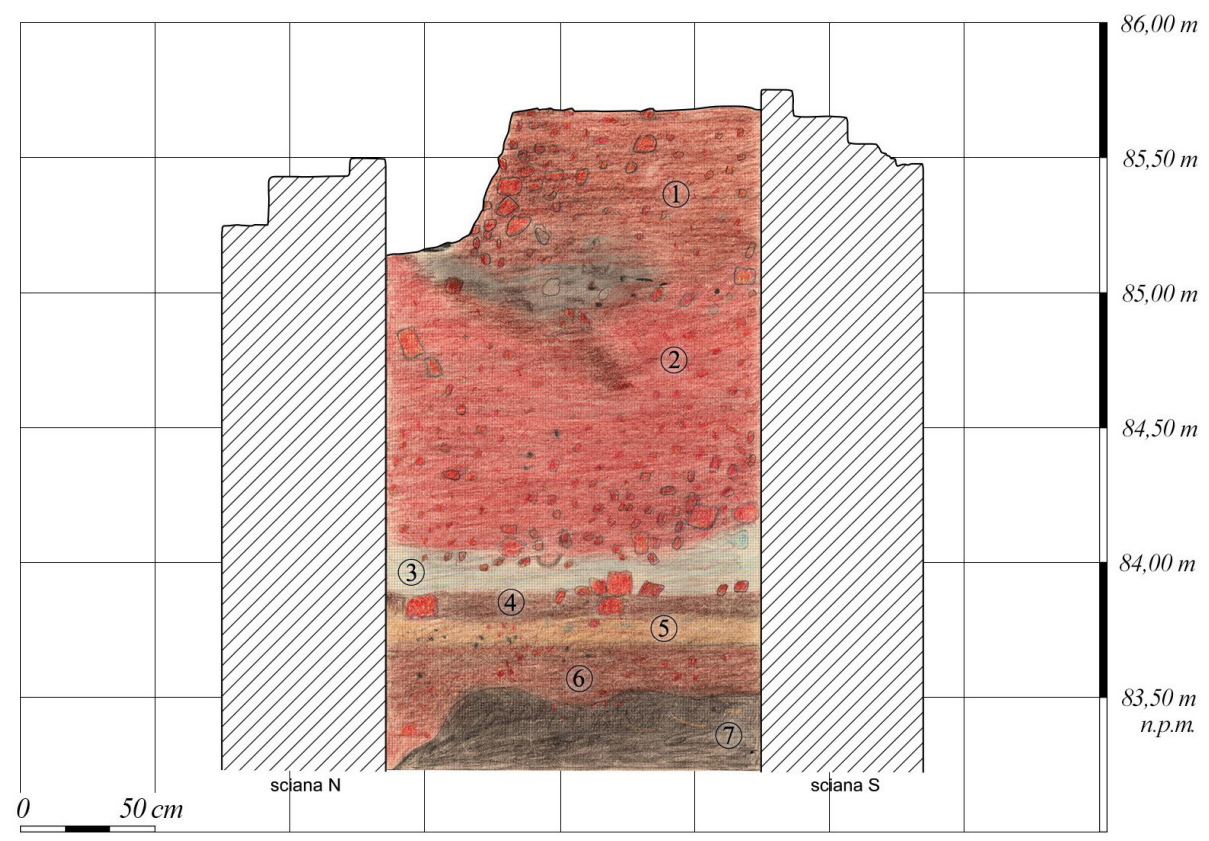

Ryc. 7. Kruszwica, stan. 2. Wykop III, profil E. Wypełnisko korytarza:

1 - ciemnobrunatna próchnica z gruzem ceglanym, zaprawą wapienną i spalenizną; 2 - jasnobrunatna próchnica $\mathrm{z}$ gruzem ceglanym i spalenizną; 3 - zaprawa wapienna $\mathrm{z}$ gruzem ceglanym i popiołem; 4 - ciemnobrunatna próchnica $z$ gruzem ceglanym i spalenizną; 5 - jasnobrunatna próchnica $z$ drobnym gruzem ceglanym, spalenizną i soczewkami żółtej gliny; 6 - brunatna próchnica z gruzem ceglanym; 7 - brunatnoczarna próchnica. Opr. J. Kurkowicz

południowa, będąca północną ścianą korytarza. Tylko zachowana ściana północna, o grubości około $1,70 \mathrm{~m}$, w której zarejestrowano dwa otwory okienne z ceglanym wykończeniem glifów, zbudowana była całkowicie z kamieni i pokryta, tak jak i fragment ściany zachodniej, tynkiem z ciemnoszarą monochromią (ryc. 8). Ponadto po zewnętrznej północnej stronie piwnicy 1 , na przedłużeniu ściany wschodniej, odsłonięto fragment kamienno-ceglanego muru o nieokreślonym przeznaczeniu, który mógłby być pozostałością po kolejnym pomieszczeniu budynku zamkowego. Piwnicę przykrywało prawdopodobnie niezachowane ceglane sklepienie kolebkowe. Wejście z korytarza do piwnicy, prawdopodobnie zwieńczone łukiem, znajdowało się $\mathrm{w}$ ścianie południowej. W licach ściany wschodniej i zachodniej odkryto ślady po osadzeniu ogniw na kajdany, a w warstwach kulturowych fragmenty samych kajdan. Wypełnisko piwnicy (ryc. 9), na poziomie użytkowym (83,55 m n.p.m.), stanowiła jednolita warstwa gruzu ceglanego z zaprawą wapienną i dachówkami, w której zarejestrowano pozostałości bruku kamiennego w postaci skupiska luźnych kamieni (ryc. 9:6). Nad nią znajdowały się warstwy jasnobrunatnej mocno 


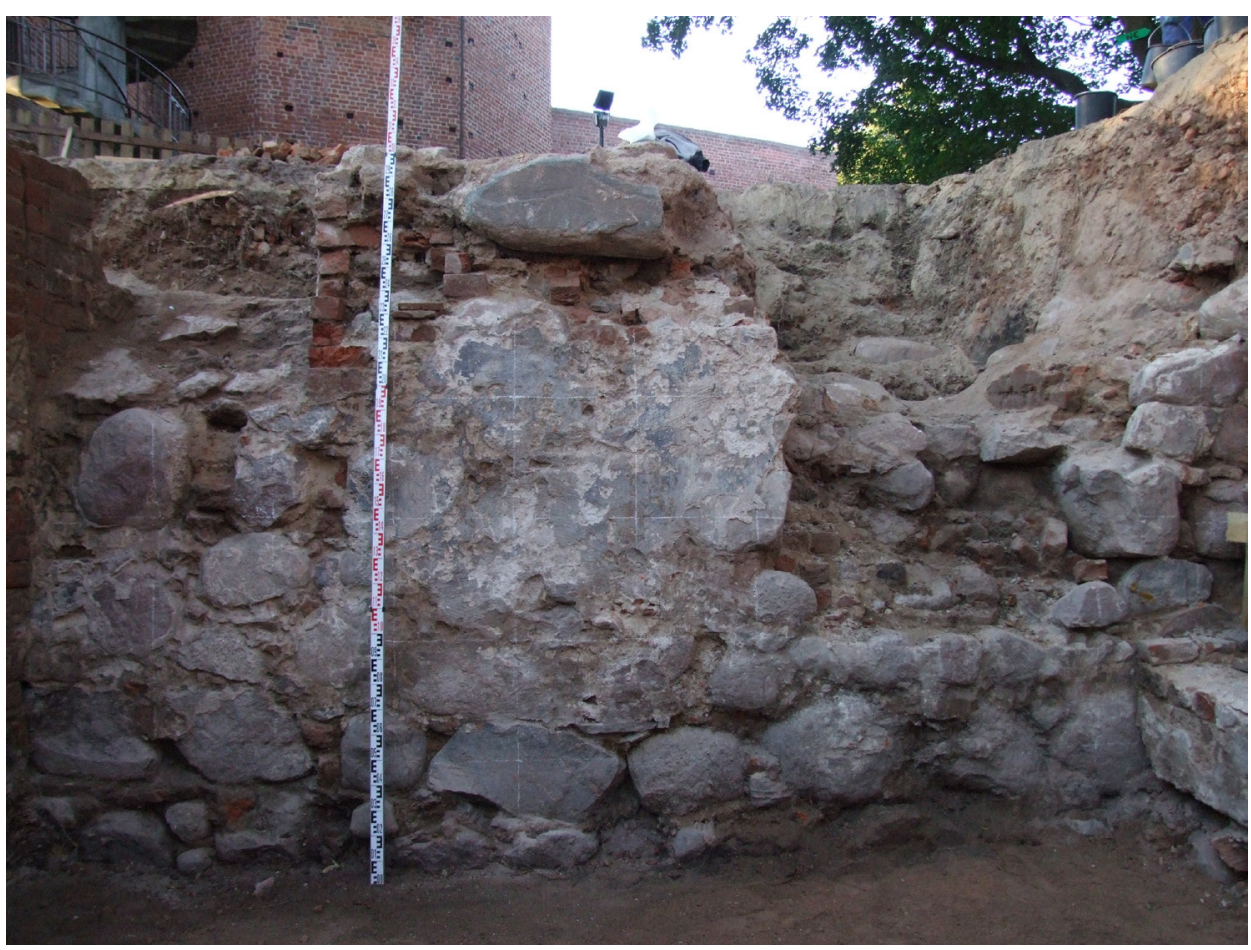

Ryc. 8. Kruszwica, stan. 2. Wykop XXXI, piwnica 1, ściana N, lico S. Zachowane dwa otwory okienne, jeden $\mathrm{z}$ nich (zachodni) z ceglanym wykończeniem glifów. Lico ściany pokryte tynkiem z ciemnoszarą monochromią. Fot. P. Pawlak

spiaszczonej próchnicy przemieszanej z gruzem ceglanym, a także destrukt sklepienia piwnicy z warstewką spalenizny, będącą prawdopodobnie śladem podłogi pierwszej kondygnacji oraz mocno spiaszczoną próchnicę przemieszaną z fragmentami cegieł i dachówek, szarą spiaszczoną próchnicę z fragmentami węgli drzewnych i cegieł oraz warstwę zaprawy wapiennej $z$ drobnym gruzem ceglanym (ryc. 9:3-5). Warstwy te były wynikiem zniszczenia zamku przez Szwedów w 1657 roku. Nad nimi znajdowały się już tylko warstwy gruzowiskowe oraz destrukty ścian, które uległy zniszczeniu po 1657 roku (ryc. 9:1, 2). W kontekście źródłowego materiału archeologicznego, który znaleziono w piwnicy, należałoby jej funkcję interpretować jako pomieszczenie dla więźniów, szczególnie po 1591 roku. Poniżej orientacyjnego poziomu użytkowego piwnicy 1 zalegała warstwa ciemnobrunatnej próchnicy przemieszanej z fragmentami węgli drzewnych, grudkami zaprawy wapiennej i drobnym gruzem ceglanym oraz ciemnobrunatna i szara próchnica. Być może są to warstwy związane $\mathrm{z}$ budową zamku $\mathrm{w}$ połowie XIV wieku lub starsze. Grunt pierwotny (calec) w postaci szarożółtej gliny zlokalizowano na poziomie $83,20-82,60 \mathrm{~m}$ n.p.m. 


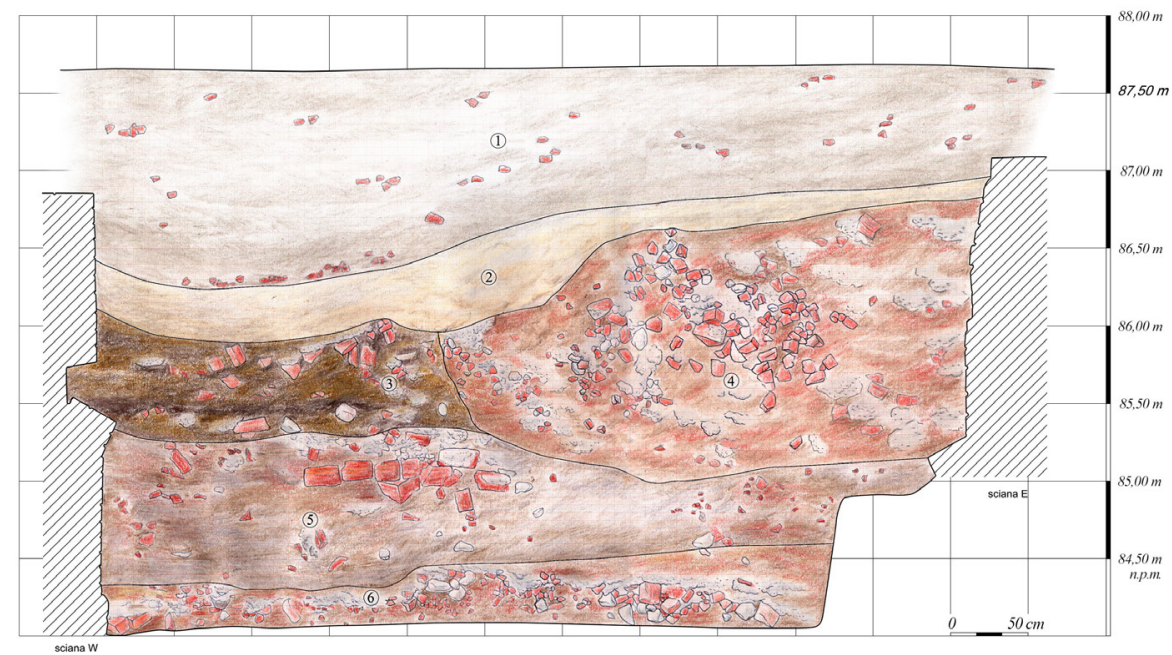

Ryc. 9. Kruszwica, stan. 2. Wykop XXXI, profil N. Wypełnisko piwnicy 1:

1 - szara próchnica przemieszana z drobnym gruzem ceglanym; 2 - warstwy gruzowiskowe i destrukty ścian; 3 - szara próchnica przemieszana $\mathrm{z}$ fragmentami cegieł i dachówek oraz warstewką spalenizny; 4 - gruz ceglany; 5 - jasnobrunatna próchnica przemieszana z gruzem ceglanym i destruktem sklepienia piwnicy; 6 - jednolita warstwa gruzu ceglanego z zaprawą wapienną, licznymi dachówkami i kamieniami. Rys. J. Kurkowicz

Piwnica 2. Odsłonięta została po południowej stronie korytarza. Jej kształt był prostokątny o maksymalnych wymiarach około $5,20 \times 4,70 \mathrm{~m}, \mathrm{z}$ wnękami o długości do około $2,20 \mathrm{~m}$ i głębokości do około $0,60 \mathrm{~m}$, zlokalizowanymi w ścianie wschodniej i zachodniej. Obie te ściany, o grubości około 1,0-2,10 m, zachowane do wysokości około 3,30-3,60 m, zbudowano z cegieł w wątku gotyckim, z wplecionym miejscami wątkiem wendyjskim. Ściana północna, zachowana do wysokości około $1,90 \mathrm{~m}$, stanowiła jednocześnie południową ścianę korytarza, $\mathrm{z}$ prawdopodobnie łukowatym wejściem do piwnicy. Ścianą południową natomiast był odsłonięty fragment muru obwodowego, zbudowany z kamieni, o grubości około $3 \mathrm{~m}$ i zachowany do wysokości około $1,75 \mathrm{~m}$. W lica ścian wpuszczone były niezachowane opory sklepień kolebkowych. W wypełnisku omawianej piwnicy najgłębiej zalegała warstwa ciemnobrunatnej próchnicy $\mathrm{z}$ gruzem ceglanym i zaprawą wapienną oraz warstwa jasnobrunatnej mocno spiaszczonej próchnicy z gruzem ceglanym i zaprawą wapienną. Były to najprawdopodobniej pozostałości sklepienia piwnicy i ślady podłogi pierwszej kondygnacji. W warstwach tych, w południowo-wschodnim narożniku piwnicy, odkryto ułożone półkoliście kamienie oraz pojedyncze cegły pochodzące najprawdopodobniej z kopuły „kominka”, który mógł tutaj powstać i funkcjonować już po pierwszym pożarze zamku w 1519 roku (ryc. 10). Prawdopodobnie $\mathrm{z}$ tym obiektem związane były nawarstwienia 
kulturowe, które uchwycono w tej części piwnicy: przepalona czarna próchnica z gliną i drobnym gruzem ceglanym, bezpośrednio na niej zalegająca cienka warstewka spalenizny z brunatną ziemią i gruzem oraz znajdująca się nad nią warstwa ciemnobrunatnej próchnicy z gruzem ceglanym i zaprawą wapienną, a także fragment skutej wschodniej ściany piwnicy, który znajdował się bezpośrednio nad „kominkiem”, a który mógł być negatywem kapy „kominka”. Do tego obiektu może też należeć ceglana konstrukcja, o wymiarach $1,10 \times 0,40 \times 0,30 \mathrm{~m}$, dostawiona do wschodniej ściany piwnicy. Wierzchnią warstwę wypełniska piwnicy stanowiła ciemnobrunatna ziemia $\mathrm{z}$ gruzem ceglanym, zaprawą wapienną i spalenizną. Wszystkie te warstwy to zapewne destrukt będący wynikiem zniszczenia zamku przez Szwedów w 1657 roku. Nad nimi znajdowały się z kolei warstwy gruzowiskowe oraz zawaliska ścian, które uległy zniszczeniu po roku 1657. Być może w omawianej piwnicy istniało ogrzewane pomieszczenie dla strażników więziennych, tym bardziej że znajdowałoby się ono naprzeciwko piwnicy 1, zinterpretowanej jako pomieszczenie dla więźniów. Poniżej orientacyjnego poziomu użytkowego (83,70 m n.p.m.) piwnicy zalegały warstwy związane prawdopodobnie z budową zamku w połowie XIV wieku: gruz i pył ceglany, jasnożółty piasek, ciemnobrunatna próchnica $\mathrm{z}$ fragmentami węgli drzewnych, drobnym gruzem ceglanym i grudkami zaprawy wapiennej, jasnoszary piasek z dużymi fragmentami węgli drzewnych oraz warstwy starsze niż połowa wieku XIV: ciemnobrunatna próchnica z drobnymi fragmentami węgli drzewnych, ciemnoszara próchnica z domieszką żółtej gliny i szara próchnica z fragmentami węgli drzewnych przemieszana z żółtą gliną. Strop gruntu pierwotnego (calca) w postaci żółtej gliny zarejestrowano na poziomie $82,60 \mathrm{~m}$ n.p.m.

Piwnica 3. Znajdowała się po zachodniej stronie korytarza i piwnic 1 i 2. Była największą z dotychczas odkrytych w całości. Jej maksymalne wymiary wynosiły $13,10 \times 5,50 \mathrm{~m}$. Długość piwnicy była jednocześnie szerokością budynku zamkowego. Ściana wschodnia piwnicy, będąca jednocześnie ścianą zachodnią piwnicy 1 i 2 , zbudowana była $\mathrm{z}$ cegieł w wątku gotyckim, miejscami w wątku wendyjskim, na kamiennym fundamencie. Ściana północna z kolei, stanowiąca również ścianę północną piwnicy 1, zbudowana była z kamieni i zachowała się do wysokości około 3,10 m. Na jej koronie udało się zaobserwować ślady ceglanego wykończenia glifu otworu oraz fragment ceglanego progu, które mogą świadczyć o istnieniu w tym miejscu zejścia do piwnicy. Tym bardziej że po zewnętrznej północnej stronie piwnicy 3, na przedłużeniu ściany wschodniej, odsłonięto fragment kamiennego muru o nieokreślonym przeznaczeniu, który mógłby być pozostałością po kolejnym pomieszczeniu budynku zamkowego. Zachodnią i południową ścianę piwnicy stanowił natomiast odsłonięty kamienny fragment muru obwodowego, o grubości około $3 \mathrm{~m}$ i zachowanej wysokości do około 1,80-3,0 m. Mur ten od strony zewnętrznej narożnika południowo-zachodniego zamku zaopatrzony był dodatkowo $\mathrm{w}$ przyporę o wymiarach około $3,50 \times 2,80 \mathrm{~m}$. Omawiana piwnica była pomieszczeniem z pewnością znacznie wyższym niż opisane powyżej piwnice 1 i 2 , ale 


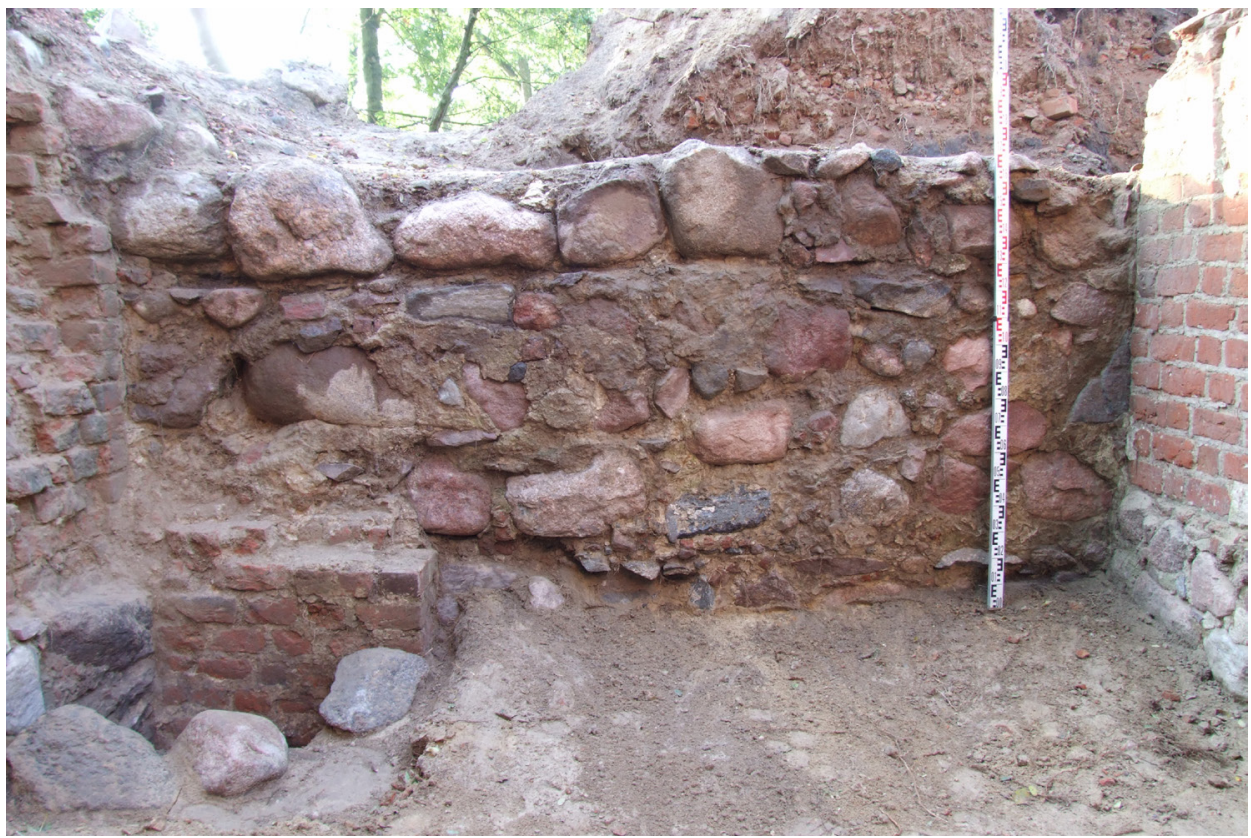

Ryc. 10. Kruszwica, stan. 2. Wykop III/XXXI, piwnica 2. Zachowane pozostałości „kominka” oraz południowego muru obwodowego. Fot. P. Pawlak

także przykrywało ją prawdopodobnie sklepienie kolebkowe, chociaż ślady takowego się nie zachowały. Wypełnisko piwnicy (ryc. 11), na orientacyjnym poziomie użytkowym (83,60 m n.p.m.) i nieco powyżej, stanowiły głównie warstwy będące najprawdopodobniej pozostałościami sklepienia piwnicy i śladami pierwszej kondygnacji. Były to warstwy żółtoszarego piasku przemieszane z drobnym gruzem ceglanym oraz ciemnobrunatnej próchnicy z gruzem ceglanym, popiołem i dużymi fragmentami węgli drzewnych (ryc. 11:4, 5). Wszystkie te warstwy to zapewne pozostałości zniszczenia zamku przez Szwedów w 1657 roku. Z kolei powyżej tych warstw, na powierzchni całego niemal pomieszczenia, zalegały warstwy gruzu ceglanego przemieszane z szarą próchnicą i warstewką zaprawy wapiennej oraz żółtoszarego piasku z drobnym gruzem ceglanym, będące pozostałościami zniszczeń dokonanych po 1657 roku (ryc. 11:2,3). Poniżej poziomu użytkowego piwnicy odnotowano warstwę mocno zbitej ciemnobrunatnej próchnicy $\mathrm{z}$ drobnym gruzem ceglanym i spalenizną oraz żółtej gliny przemieszanej z drobnym gruzem ceglanym (ryc. 11:6, 7). Warstwy te mogły być związane z budową zamku w połowie XIV wieku. Zarejestrowano również układ warstw prawdopodobnie starszych niż połowa XIV wieku w postaci ciemnobrunatnej próchnicy ze spalenizną i szarej próchnicy. Strop gruntu pierwotnego (calca) zanotowano miejscowo już na głębokości około 83,00 m n.p.m. 


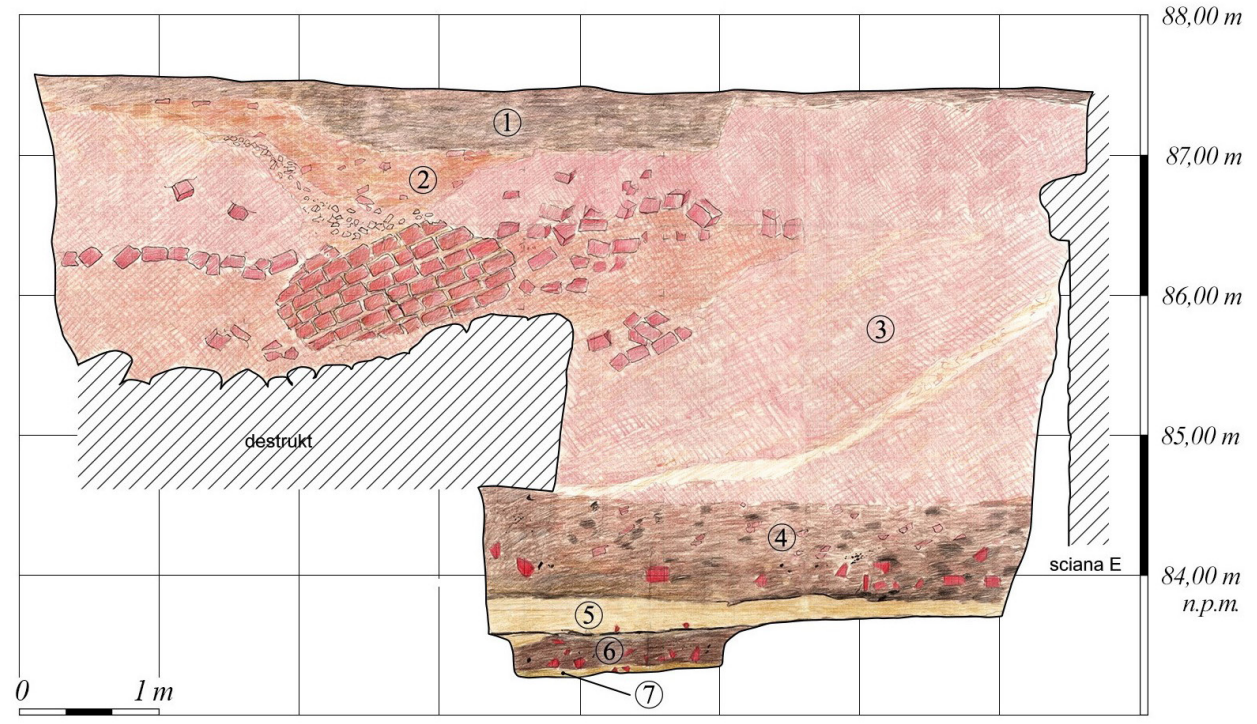

Ryc. 11. Kruszwica, stan. 2. Wykop III, profil W. Fragment wypełniska piwnicy 3:

1 - szara próchnica (humus); 2 - żółtoszary piasek z drobnym gruzem ceglanym; 3 - gruz ceglany z szarą próchnicą i warstewką zaprawy wapiennej; 4 - ciemnobrunatna próchnica z gruzem ceglanym, popiołem i dużymi fragmentami węgli drzewnych; 5 - żółtoszary piasek z drobnym gruzem ceglanym; 6 - ciemnobrunatna próchnica z drobnym gruzem ceglanym i spalenizną; 7 - żółta glina z drobnym gruzem ceglanym. Rys. K. Poprawski. Opr. J. Kurkowicz

W części środkowej piwnicy odsłonięto pozostałości zrębowej konstrukcji drewnianej, o wymiarach około $1,10 \times 1,30 \mathrm{~m}$. Wypełnisko obiektu stanowiła ciemnobrunatna próchnica $\mathrm{z}$ fragmentami gruzu ceglanego, a także przepalone ziarna owsa i pszenicy. Należy też dodać, że deski, z których wykonano omawianą konstrukcję, także były spalone. W kontekście znalezionych ziaren zbóż należałoby interpretować funkcję obiektu jako gospodarczo-magazynową (,piwniczka” zasobowa). Całość konstrukcji umieszczona została w wykonanym wkopie o szerokości około 2,45 m i zasypanym szarą i ciemnobrunatną próchnicą przemieszaną z żółtym piaskiem, gruzem ceglanym, zaprawą wapienną i fragmentami węgli drzewnych. Inwestycji dokonano najprawdopodobniej po pożarze zamku w 1519 lub 1591 roku. Wkop z kolei zrobiono w warstwach ciemnobrunatnej próchnicy ze spalenizną i fragmentami węgli drzewnych, zapewne starszych niż połowa XIV wieku. Strop gruntu pierwotnego (calca) w postaci żółtej lekko spiaszczonej gliny zarejestrowano miejscami już na poziomie $82,79 \mathrm{~m}$ n.p.m.

Piwnica 4. Zlokalizowana została po wschodniej stronie korytarza i piwnic 1 i 2. Jej całkowitych wymiarów nie udało się ustalić, gdyż eksploracji poddano tylko część południowo-zachodnią. Długość, wzdłuż ściany zachodniej, stanowiącej również ścianę wschodnią piwnicy 1 i 2, mogła wynosić około 12,30 m. Szerokość 


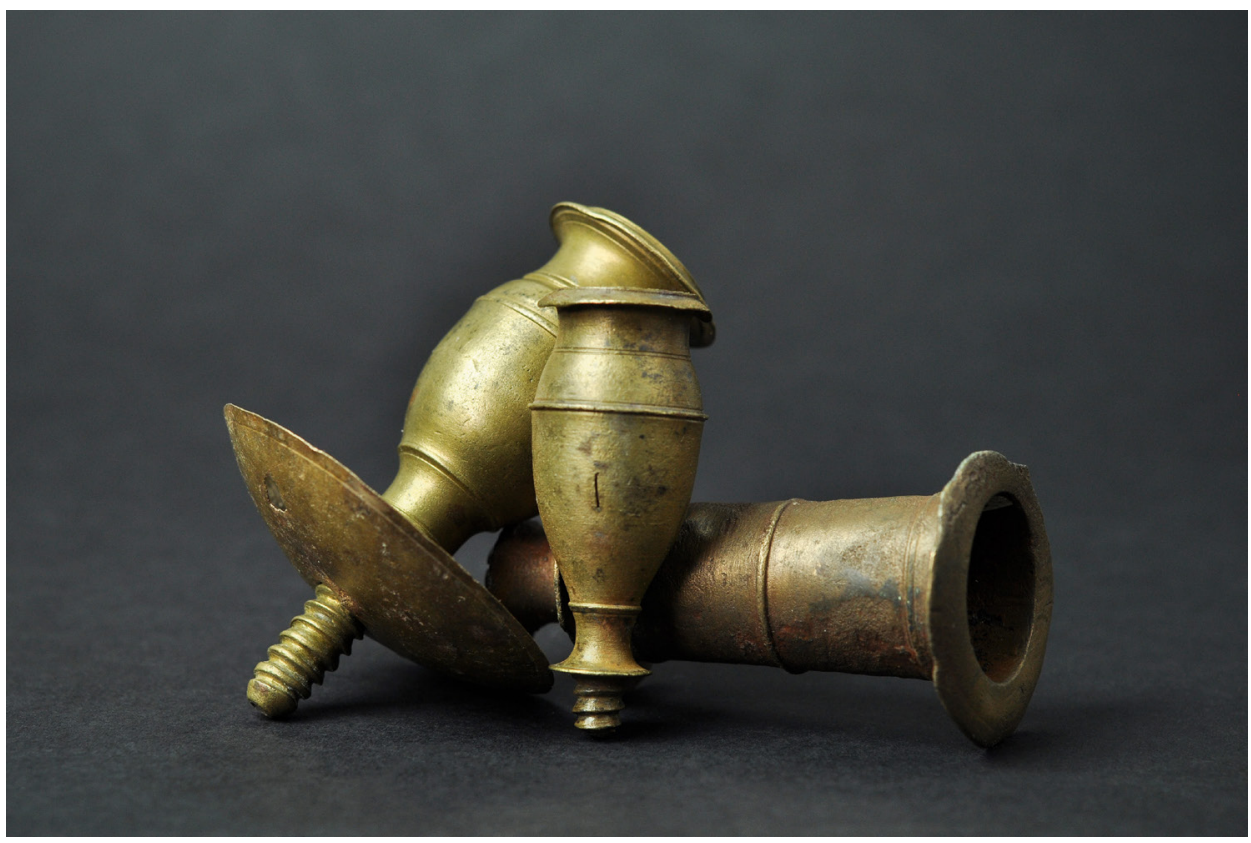

Ryc. 12. Kruszwica, stan. 2. Świeczniki. Fot. J. Kurkowicz

natomiast mogła mieć nawet do około $10 \mathrm{~m}$, gdyż w tej odległości od niej odkryto fragment, być może, wschodniej ściany piwnicy, w postaci kamiennych fundamentów o odsłoniętej długości do około $2,50 \mathrm{~m}$, szerokości około $1 \mathrm{~m}$ oraz wysokości około $2,37 \mathrm{~m}$. W licu ściany zachodniej, odsłoniętej na wysokość około 3,50 m, odnotowano istnienie czterech gniazd po belkach, prawdopodobnie stropowych, umieszczonych po dwie, po obu stronach przejścia do korytarza oraz wnękę szafy o wymiarach około $0,70 \times 0,60 \mathrm{~m}$. Fragment ściany południowej piwnicy to kamienny fundament muru obwodowego zamku zachowany $\mathrm{w}$ tym miejscu na wysokość około 2,20 m. Wypełnisko piwnicy stanowiła głównie brunatna i ciemnobrunatna próchnica $z$ gruzem ceglanym, zaprawą wapienną i spalenizną, będąca silnie przemieszanymi warstwami destrukcyjnymi powstałymi zarówno w trakcie zniszczenia zamku w 1657 roku, jak i po nim. W warstwach tych, na głębokości 84,59-84,85 m n.p.m., natrafiono na fragmenty belek drewnianych, których dosyć regularny układ może sugerować pozostałości drewnianego stropu i podłogi pierwszej kondygnacji zamku, a znalezione na głębokości 84,47$-84,67$ m n.p.m. płytki posadzkowe mogą wskazywać na zachowane resztki ceramicznej posadzki. Ponadto $\mathrm{w}$ narożniku południowo-zachodnim piwnicy odkryto ceglaną „komorę”, o wymiarach około 1,85 × 1,40 m, której wypełnisko stanowiła ciemnobrunatna próchnica $\mathrm{z}$ gruzem ceglanym i spalenizną. Przylegała ona do muru obwodowego oraz do zewnętrznego lica wschodniej ściany piwnicy $2 \mathrm{w}$ miejscu 


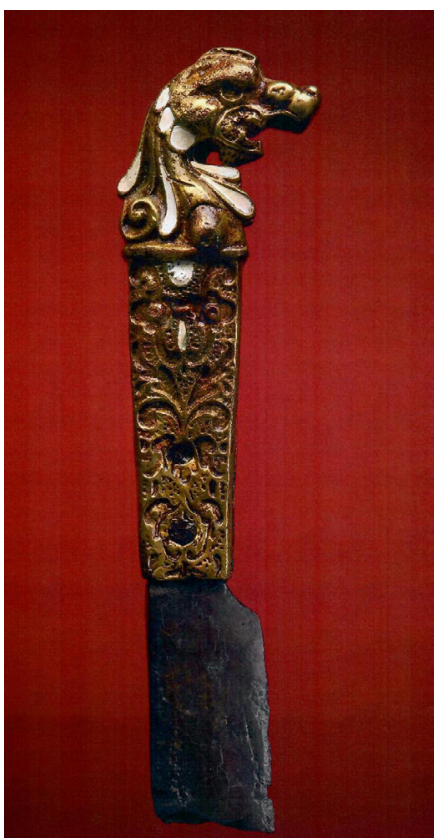

Ryc. 13. Kruszwica, stan. 2.

Nóż stołowy. Fot. M. Jórdeczka

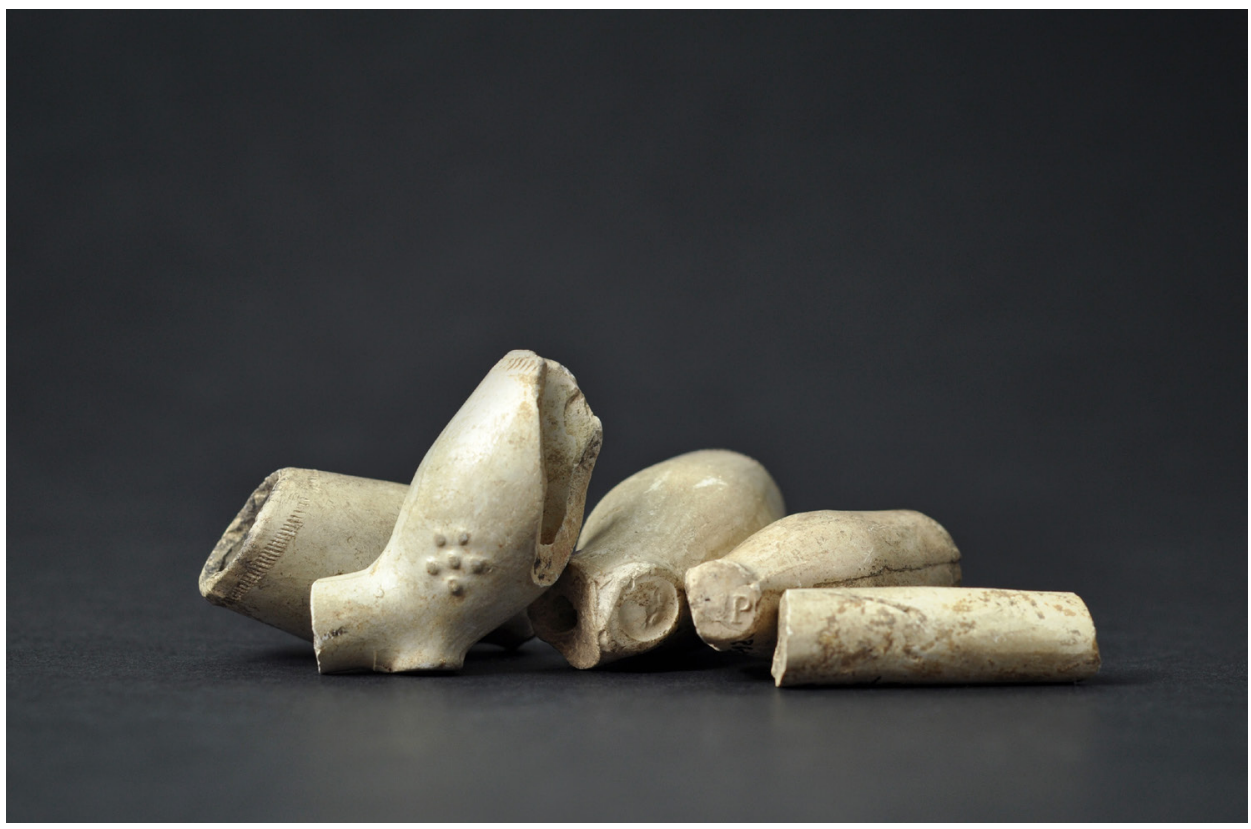

Ryc. 14. Kruszwica, stan. 2. Fragmenty fajek z glinki kaolinowej. Fot. J. Kurkowicz 
występowania w niej „kominka”. Ściany „komory” odsłonięto na wysokość około 0,60 m. Ich grubość wynosiła około 0,25-0,50 m. Być może „komora” ma związek $\mathrm{z}$ ogrzewaniem typu hypocaustum, tym bardziej że w jej wypełnisku znaleziono m.in. płytki z otworem, charakterystyczne dla tego typu ogrzewania. Funkcji samej piwnicy nie udało się ustalić.

W latach 2007-2008 w wykopach badawczych zlokalizowanych na krawędziach Wzgórza Zamkowego odkryto pozostałości muru obwodowego zamku, a także relikty przejścia bramnego. Fragmenty kamiennych fundamentów muru obwodowego, o grubości od około 1,20 do 3,60 m, odsłonięto miejscami na maksymalną wysokość do około 1,40 m. Odkryte fragmenty zalegały w nowożytnych i współczesnych warstwach kulturowych związanych z ich rozbiórką po zniszczeniu zamku w 1657 roku oraz pracami budowlanymi w XIX wieku. Były to głównie warstwy szarej, ciemnoszarej, brunatnej i ciemnobrunatnej próchnicy przemieszane często $\mathrm{z}$ gruzem ceglanym i zaprawą wapienną. W kilku wykopach natrafiono na stropy ciemnoszarej i ciemnobrunatnej próchnicy, która mogła stanowić pierwotną warstwę kulturową, starszą niż połowa XIV wieku, w którą wkopano fragmenty fundamentów muru obwodowego. Eksplorację w wykopach badawczych kończono zwykle po odkryciu pozostałości konstrukcji murów. Podobne warstwy zasypiskowo-rozbiórkowe, jak opisane powyżej, przykrywały również pozostałości przejścia bramnego zamku, odkrytego w północnej części Wzgórza Zamkowego, w postaci zachowanych kamiennych fundamentów spojonych zaprawą wapienną. Relikty przejścia odsłonięto miejscami na maksymalną wysokość około $4,45 \mathrm{~m}$. W rzucie poziomym przejście miało kształt $\mathrm{w}$ przybliżeniu prostokątny, o wymiarach około $5,20 \times 1,50 \mathrm{~m}$. Grubość ścian wynosiła od około 1,25-2 $\mathrm{m}$ do około $2,50 \mathrm{~m}$. Ścianę zachodnią konstrukcji stanowiła przypora, o długości około 5,50 m, związana konstrukcyjnie z murem obwodowym, o grubości około 3,60 m, który z kolei był jej ścianą południową. Po wschodniej i południowej stronie bramy uchwycono strop ciemnobrunatnej próchnicy, w którą wkopane były pozostałości omawianej konstrukcji przejścia bramnego, a które z pewnością były starsze niż połowa wieku XIV.

Uzupełnieniem całościowego obrazu rozplanowania założenia zamkowego mogą być odkrycia późnośredniowiecznych fos, dokonane na stanowiskach nr 5 i $4 \mathrm{a}$ w latach 1948-1949 i 1974. Na stanowisku nr 5, w dwóch wykopach zlokalizowanych po północno-wschodniej stronie Wzgórza Zamkowego, odkryto pozostałości fosy zamkowej o głębokości do około 2 m (Jakimowicz 1952, s. 113-116; Hensel i Cofta 1953, s. 614-625). Fosa ta wypełniona była warstwami kulturowymi powstałymi po zniszczeniu Zamku w 1657 roku. Pozostałości fosy odkryto także w południowej części stanowiska nr 4a. Wkopana była w wał wczesnośredniowiecznego obronnego podgrodzia. Szerokość jej dochodziła do $15,5 \mathrm{~m}$, a zachowana głębokość do 1,5 m (Dzieduszycki 1984, s. 167-183).

W trakcie prowadzonych badań wykopaliskowych wydobyto bardzo liczne i różnorodne kategorie ruchomych źródeł archeologicznych. Większość z nich 
pochodzi jednak z okresu po 1591 roku oraz z czasów szwedzkiej okupacji zamku i jego zniszczenia w 1657 roku (Dzieduszycki 2014, s. 36-51). Podkreślić trzeba, że znalezione przedmioty świadczą o osobliwej roli zamku w Kruszwicy i o wyjątkowości jego mieszkańców. Spośród znalezisk na szczególną uwagę zasługują elementy architektury zamkowej w postaci kamiennych ciosów, fragmentów odrzwi i kamieniarki okiennej, ceglane kształtki czy dachówki. Z wyposażenia wnętrz zachowały się pozostałości pieców w postaci kafli, szkliwione płytki z otworami, fragmenty szyb okiennych ze śladami po ołowianej oprawie i resztkami napisów („Macziey...a Starosta...”). Znaleziono też żelazne zawiasy drzwi, wrzeciądza, haki i haczyki, klucze, kłódki, klamki i antaby, ozdobne okucia. Liczne znaleziska gwoździ i skobli uzupełniają listę elementów wyposażenia pomieszczeń zamku w Kruszwicy. Niektóre izby w zamku oświetlano zapewne mosiężnymi świecznikami - znalezione trzy okazy oraz jeden okapnik (ryc. 12). W trakcie badań wykopaliskowych, we wszystkich wykopach badawczych, odkryto liczne przykłady zamkowej zastawy kuchennej i stołowej, w postaci ułamków glinianych talerzy, mis, kubków i dzbanów, a także fragmenty szklanych butelek i butli, pucharków, kielichów, szklanek czy czarek. Natrafiono także na znaleziska noży stołowych, jeden z nich z emaliowaną rękojeścią (ryc. 13). O randze ówczesnych mieszkańców zamku świadczy chociażby obecność przedmiotów związanych z higieną, takich jak grzebienie czy szpatułki kosmetyczne. Z warstw destrukcyjnych 1657 roku pochodzą fragmenty fajek wykonanych z glinki kaolinowej (ryc. 14). W użyciu były także wytwory luksusowe, jak złoty pierścień oraz tarczka małego zegara (pektoralika), na której wyryto wyobrażenie bliżej nieokreślonego zamku wraz z murami obronnymi (ryc. 15). Znaleziono także cenne okazy numizmatów w postaci monet, $\mathrm{z}$ których najstarsza reprezentowana jest przez szeląg mistrza krzyżackiego Michała Kuechmeistra von Sternberga z lat 1414-1416, a najmłodsza natomiast przez grosz miedziany z 1783 roku wybity przez Stanisława Augusta Poniatowskiego. Wśród najstarszych elementów uzbrojenia znalezionych podczas badań wykopaliskowych wymienić można licznie odkrywane żelazne groty bełtów kusz i elementów spustowych kusz w postaci tzw. orzechów, fragment głowni broni siecznej (ryc. 16) oraz pozostałości zbroi płytowej (ryc. 17). Znaleziono też kamienne kule armatnie i ołowiane kule do muszkietów, a także ozdobne wieczko ładownicy prochowej (ryc. 18). Z uzbrojeniem można także łączyć ostrogi czy sprzączki z uprzęży końskiej, a także wędzidła i podkowy. W zamku mieściło się archiwum grodzkie, z którego ocalały jedynie dwie księgi z lat 1585 i 1586, a także brązowe okucia ksiąg. 


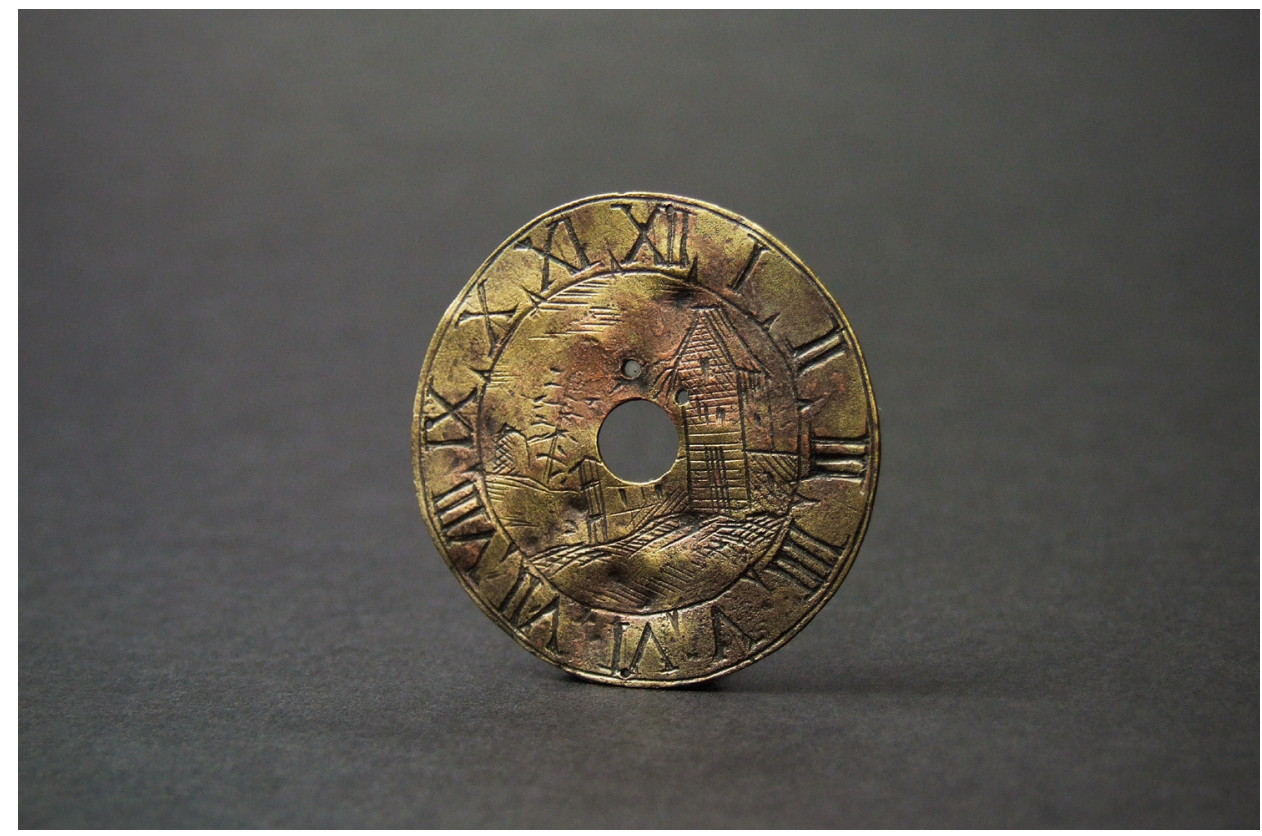

Ryc. 15. Kruszwica, stan. 2. Tarcza zegara (pektoralika). Fot. J. Kurkowicz

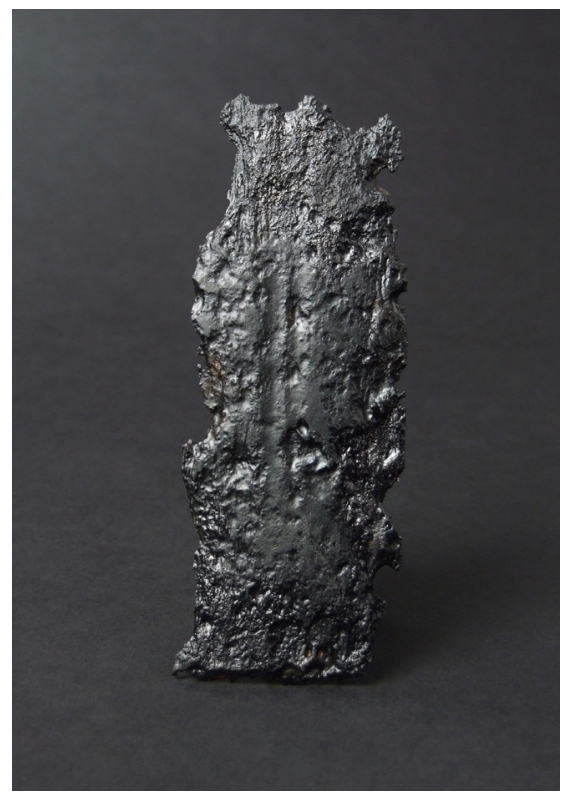

Ryc. 16. Kruszwica, stan. 2. Fragment głowni broni siecznej. Fot. J. Kurkowicz 


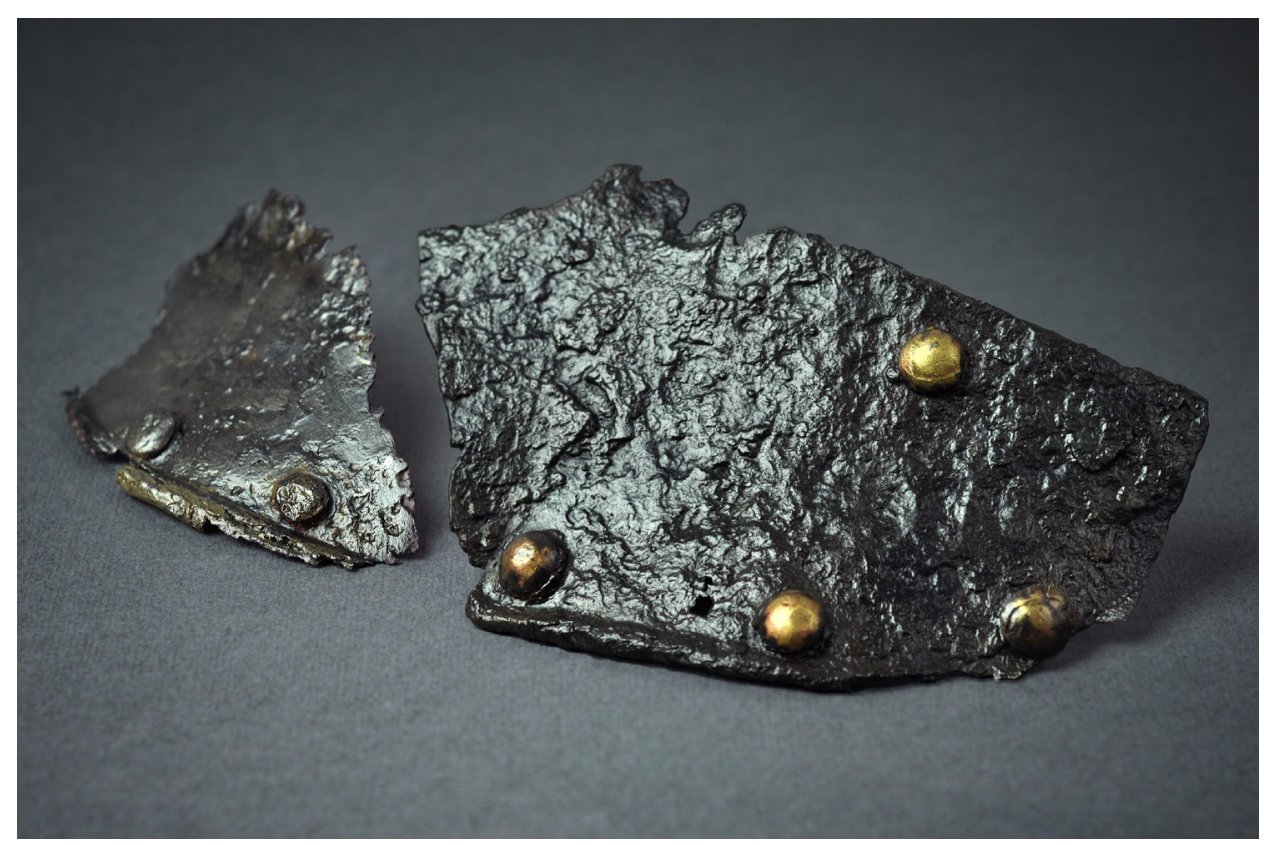

Ryc. 17. Kruszwica, stan. 2. Fragmenty zbroi płytowej. Fot. J. Kurkowicz

\section{PODSUMOWANIE}

W trakcie istnienia i funkcjonowania Zamku w Kruszwicy do czasu zniszczenia go przez Szwedów w 1657 roku odnotowano dwa ważne wydarzenia, które pozostawiły trwały ślad w jego architekturze i układach warstw kulturowych. Były to dwa pożary, jeden w 1519 i drugi w 1591 roku. Po nich następowały okresy odbudowy bądź też rozbudowy zamku. Na podstawie przeprowadzonej analizy stratygraficznej można stwierdzić, że zmiany te najbardziej czytelne są zarówno w odkrytych zachowanych reliktach ,kamienicy” zamkowej, jak i w warstwach kulturowych w środkowej części Wzgórza Zamkowego. Najmniej czytelne są one w wykopach badawczych, które odsłoniły przebieg muru obwodowego i zlokalizowały przejście bramne.

Biorąc pod uwagę wyniki powyższych analiz, analiz architektonicznych (Maciejewski 2014, s. 89-113) oraz rezultaty badań próbek radiowęglowych ${ }^{14} \mathrm{C}$, możemy wyróżnić w historii istnienia i funkcjonowania Zamku w Kruszwicy cztery okresy chronologiczne: okres I - od połowy XIV wieku do 1519 roku; okres II 1519 do 1591 roku; okres III - 1591 do 1657 roku; okres IV - po 1657 rok. Dodatkowo można stwierdzić, na podstawie odkryć i interpretacji archeologicznych, że odsłonięte pozostałości „kamienicy” zamkowej posiadały piwnice oraz jedną kondygnację, $\mathrm{w}$ parterze. $\mathrm{Z}$ ocalałych lustracji zamku oraz rysunku 


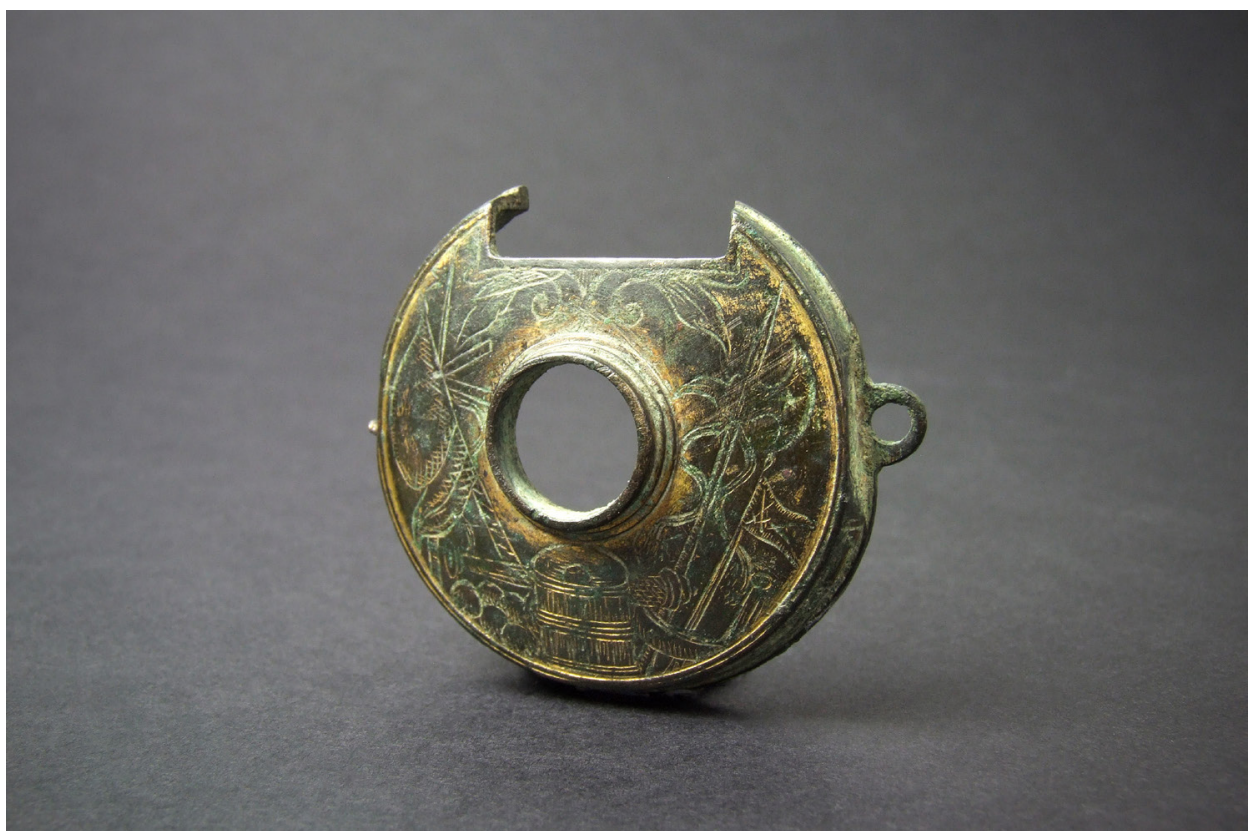

Ryc. 18. Kruszwica, stan. 2. Wieczko ładownicy prochowej. Fot. J. Kurkowicz

E.J. Dahlbergha wynika jednak, że budynek zamkowy miał co najmniej jeszcze jedno piętro z poddaszem. Niestety, w nawarstwieniach kulturowych nie udało się tego uchwycić, być może dlatego, że zamek po zniszczeniu go przez Szwedów w 1657 roku pozostał w ruinie, a jego resztki rozbierano na przestrzeni bez mała 200 lat, wykorzystując materiał budowlany do budowy innych obiektów w mieście (Maciejewski 2014, s. 53-87). Ocalało jedynie to, co znajdowało się poniżej poziomu gruntu, a więc pomieszczenia piwniczne zamkowej „kamienicy”, a także pozostałości fundamentów muru obwodowego i przejścia bramnego. Ponadto zachowane fragmenty konstrukcji kamienno-ceglanych po zachodniej i północnej stronie odkrytego budynku sugerują istnienie dalszej zabudowy tej części Wzgórza Zamkowego.

\section{BIBLIOGRAFIA}

Dzieduszycki W. 1984, Wczesnośredniowieczna przeprawa przez Gopło, „Sprawozdania Archeologiczne" 36, s. 167-183.

- 1984a, Socjotopograficzne przeobrażenia wczesnośredniowiecznych miast polskich (model kruszwicki), „Kwartalnik Historii Kultury Materialnej” 32 (1), s. 3-21.

- 2014, Dzieje Zamku Kruszwickiego, w: W. Dzieduszycki, M. Maciejewski, M. Małachowicz (red.), Zamek Kruszwicki, Kruszwica, s. 15-52. 
Dzieduszycki W., Maciejewski M., Małachowicz M. (red.) 2014, Zamek Kruszwicki, Kruszwica.

Frycz J. 1965, Układ urbanistyczny i zabytki architektury Kruszwicy, w: J. Grześkowiak (red.), Kruszwica. Zarys monograficzny, Toruń.

Górski K. 1965, Dzieje Kruszwicy do końca XVIII w., w: J. Grześkowiak (red.), Kruszwica. Zarys monograficzny, Toruń.

Hensel W., Cofta A., 1953, Badania archeologiczne w Kruszwicy w 1952 roku, „Przegląd Zachodni”, R. 9, nr 4/5, s. 614-625.

Hensel W., Broniewska A. 1961, Starodawna Kruszwica, Wrocław.

Jakimowicz R. 1952, Sprawozdanie z prac wykopaliskowych w Kruszwicy w latach 1948-1949, „Studia Wczesnośredniowieczne", t. 1, s. 113-116.

Maciejewski M. 2014, Zamek Kruszwicki po 1657 roku, upadek i odrodzenie, w: W. Dzieduszycki, M. Maciejewski, M. Małachowicz (red.), Zamek Kruszwicki, Kruszwica, s. 53-87.

Małachowicz M. 2014, Średniowieczny Zamek Kruszwicki. Próba rekonstrukcji, w: W. Dzieduszycki, M. Maciejewski, M. Małachowicz (red.), Zamek Kruszwicki, Kruszwica, s. 89-113.

Pawlak P. 1993, Z badań archeologiczno-architektonicznych zamku w Kruszwicy w latach 1973-1982, „Wielkopolskie Sprawozdania Archeologiczne” 2, s. 215-232. 